\title{
The correlation between total lymphocyte count and the number of candida colony from the oral cavity in HIV/AIDS patients
}

\author{
Herdiman T Pohan
}

\begin{abstract}
Abstrak
Infeksi HIV menyebabkan menurunnya jumlah sel T helper(Th) yang memudahkan terjadinya infeksi oportunistik. Salah satu infeksi oportunistik tersering adalah infeksi kandida di orofaring dan esofagus. Untuk mendeteksi peningkatan koloni Kandida tidak mudah, jumlah CD4 dapat digunakan sebagai rujukan. Pada kenyataannya hanya sedikit sentra laboratorium yang menyediakan fasilitas pemeriksaan CD4. Dilakukan penelitian cross-sectional untuk menentukan hubungani antara jumlah limfosit total dengan intensitas koloni kandida di orofaring pasien-pasien HIV/AIDS. Penelitian dilakukan di poliklinik dan bangsal rawat inap RS Dr. Cipto Mangunkusumo dari Agustus 2004 sampai Januari 2005. Subyek penelitian diwawancarai, menjalani pemeriksaan fisik, dan pemeriksaan darah dan kultur sampel kumur pasien. Sejumlah 60 subyek terdiri dari 52 pria(86.7\%) dan 8 wanita(13.3\%). Rata-rata hitung limfosit total adalah $1194.53 \mathrm{sel} / \mu \mathrm{L}$. Kandidosis orofaring terdapat pada 44 pasien(73.3\%).Terdapat kecenderungan jumlah koloni Kandida yang tinggi pada jumlah limfosit total pasien yang rendah, walaupun tidak terdapat korelasi signifikan di antara keduanya. Terdapat perbedaan yang bermakna antara jumlah limfosit total pada klas koloni Kandida yang positif dan negatif. (Med J Indones 2005; 14: 147-51)
\end{abstract}

\begin{abstract}
HIV infection causes qualitative and quantitative reduction of the Thelper (Th) subset of T lymphocytes, facilitating opportunistic infection. One of the common opportunistic infections among HIV/AIDS patients is Candida infection in the oropharynx and esophagus. Detection of increased Candida colonialization is not always easy, CD4 count is a parameter that could be used as reference. The fact is there's only few laboratory can provide CD4 count. This study is a cross-sectional correlative study to determine the relation between total lymphocyte count as a much more applicable laboratory parameter and the intensity of Candida colonization in the oropharyngeal cavity of patients with HIV infection/AIDS. It was performed in the outpatient ward and inpatient ward of Dr. Cipto Mangunkusumo Hospital, from August 2004 to January 2005. The selected study subjects underwent interview, physical examination and had their blood samples and gargle samples taken. 60 study subjects were recruited, consisting of 52 males $(86.7 \%)$ and 8 females (13.3\%). The mean total lymphocyte count was 1194.53 cells/ $\mu$ L. Oropharyngeal candidiasis was found in 44 subjects (73.3\%). There is a trend of higher Candida colonies number with lower total lymphocyte count despite no significant correlation between total lymphocyte count and the number of Candida colonies in the oral cavity of patients with HIV infection/AIDS. There is significant different between total lymphocyte count in positive and negative Candida colonies. (Med J Indones 2005; 14: 147-51)
\end{abstract}

Keywords: Total lymphocyte count, oral candidiosis, candida colony, HIV/AIDS

Human Immunodeficiency Virus (HIV) infection and Acquired Immune Deficiency Syndrome (AIDS), are highly significant problems in various countries in the world, including Indonesia. ${ }^{1}$

HIV infection causes qualitative and quantitative reduction of the $\mathrm{T}$ helper (Th) subset of $\mathrm{T}$ lymphocytes. This reduction in Th causes a reduction in the

Division of Infectious and Tropical Diseases, Department of Internal Medicine, Faculty of Medicine, University of Indonesia / Dr. Cipto Mangunkusumo Hospital, Jakarta, Indonesia patients' immune system, ${ }^{2,3}$ facilitating opportunistic infection due to fungi, bacteria, virus, and parasites, causing a significant increase in morbidity and mortality rate among AIDS patients. ${ }^{2.3 .4}$ One of the common opportunistic infections among HIV/AIDS patients is infection by Candida spp. ${ }^{5}$

Candida is normally found in various human body parts such as the oropharyngeal and gastrointestinal mucosa, and does not cause infection as long as the ecological balance of the intact skin and mucosal surface is maintained and the host's immune response is well-functioning. ${ }^{6}$ Candida albicans is the candida genus that most commonly cause infections in 
humans. Aside from C. Albicans, infections by Candida other than C. albicans are also commonly found among patients with HIV infection/AIDS. ${ }^{7-9}$

At Dr. Cipto Mangunkusumo Hospital, a study on the prevalence of oropharyngeal and esophageal Candida infection among HIV/AIDS patients has been performed by finding oral thrush through clinical examination without laboratory confirmation. From this study, we found an $80.8 \%$ prevalence of Candida infection in the oropharynx and esophagus of HIV/AIDS patients. ${ }^{4}$ Other studies abroad mentioned a prevalence of oropharyngeal candidiasis among patients with HIV infection/AIDS of $80 \%$ to $95 \%$. $^{9,10}$

Oropharyngeal candidiasis could cause more severe clinical impacts on the patients because they cause discomfort in the oropharyngeal cavity up to difficulty swallowing, reducing dietary and fluid intake, and eventually reducing quality of life. ${ }^{11}$

Even though oral thrush may be caused by things other than fungal infection, the laboratory examination for the diagnosis of oropharyngeal candidiasis, including in HIV/AIDS patients at Dr. Cipto Mangunkusumo Hospital, is very rarely undertaken. Most patients with oral thrush are immediately treated with antifungals. ${ }^{12}$ This of course could result in incorrect treatment or other unwanted effects such as resistance to anti-fungals.

Detection of increased Candida colonialization is not always easy. Therefore, another parameter is needed to determine this. Actually, CD4 count is a parameter that could be used as reference, because it is known to influence fungal elimination. However, the relatively high cost for this examination makes most patient refuse to have it undertaken. Another problem is that this examination still not available in most remote areas in Indonesia. Studies on total lymphocyte count as a predictor of CD4 count in HIV/AIDS patients itself has been performed by Lydia in Jakarta, with equation results between CD4 count and total lymphocyte of CD4=0.3 by lymphocyte count -8.2 . The determinant coefficient for this equation is $82.3 \%{ }^{13}$

This study was performed to find another more affordable laboratory parameter that can be used as reference, which are total lymphocyte count. Aims of this study is to find the correlation between total lymphocyte count and increased Candida colony intensity in the oropharyngeal cavity of patients with HIV/AIDS infection. Knowledge of this data will hopefully facilitate the identification of increased colonization and Candida infection, allowing more effective and better aimed management.

\section{METHODS}

This study design is a cross-sectional correlative study was performed in the outpatient unit and inpatient ward of Cipto Mangunkusumo Hospital, Jakarta, from August 2004 to January 2005. Laboratory examination for Candida was performed at the Parasitology laboratory, Faculty of Medicine of the University of Indonesia.

The study subjects were inpatients and outpatients with HIV/AIDS between August 2004 to January 2005. The inclusion criteria were patients with HIV infection who were able to undergo gargle testing and was not on anti-fungal treatment within at least the past week, while the exclusion criteria was refusal to participate in the study. Samples were recruited consecutively until the target number of samples was obtained. The selected study subjects underwent interview, physical examination and data collection, and then had blood samples taken for total lymphocyte count and had gargle samples taken using $40 \mathrm{cc}$ of sterile distilled water in the morning prior to having their breakfast or brushing their teeth. The sample is cultured in CHROM agar media by pouring $1 \mathrm{ml}$ of the homogenous gargle results in the media, and after the fungi grows, the Candida colonies were counted from each Petri dish from each gargle sample.

Data management and analysis were performed using the SPSS software version 10.1 for Windows. The correlation between total lymphocyte count and Candida colonization intensity in the oropharyngeal cavity of patients with HIV infection/AIDS is analyzed by Spearman's correlation test.

\section{RESULTS}

During the course of the study, 60 subjects were recruited, consisting of 52 males $(86.7 \%)$ and 8 females $(13.3 \%)$. We could see the distribution of subjects according to age group in Table 1 . 
Table 1. Subject characteristics according to sex, age group and HIV transmission $(n=60)$

\begin{tabular}{|c|c|c|}
\hline Characteristics & Number & Percentage \\
\hline \multicolumn{3}{|l|}{ Sex ${ }^{*}$} \\
\hline Male & 52 & 86.7 \\
\hline Female & 8 & 13.3 \\
\hline \multicolumn{3}{|l|}{ Age group $\#$} \\
\hline$<20$ years & 1 & 1.7 \\
\hline $20-24$ years & 24 & 40 \\
\hline $25-30$ years & 27 & 45 \\
\hline$>30$ years & 8 & 13.3 \\
\hline \multicolumn{3}{|l|}{ HIV transmission } \\
\hline Syringe & 45 & 75 \\
\hline Sex & 11 & 18.3 \\
\hline Syringe dan sex & 4 & 6.7 \\
\hline
\end{tabular}

* Chi-Square test $\mathrm{p}<0.05$

\# Chi-Square test $\mathrm{p}<0.05$

The most frequent HIV transmission in the study subjects is through the syringe of intravenous drug users, found in 45 subjects (75\%), followed by sexual transmission in 11 subjects $(18.3 \%)$, while transmission through syringe and sex was found in 4 subjects (6.7\%).

The median total lymphocyte count for subjects are 982 cells $/ \mu 1$, with a minimum of 162 cells $/ \mu 1$ and maximum of 3166 cells/ $\mu 1$. The mean total lymphocyte count among subjects is 1194.5 cells $/ \mu \mathrm{L}$, and Standard Deviation 875.51. The distribution of data measured by Kosmogorov-Smirrnoff is not normal with $\mathrm{p}<0.05$.

Table 2. Result of Candida Culture

\begin{tabular}{rcc}
\hline & Number & Percentage \\
\hline Oropharyng Candidiasis & & \\
Positive Culture & 44 & 73.3 \\
Negative culture & 16 & 26.7 \\
\hline
\end{tabular}

From the Candida culture from the subjects' oropharyngeal cavity, the median number of Candida colonies that grows in one Petri dish from one gargle sample is 159.5 colonies $/ \mu \mathrm{L}$, with a minimum count of 0 colonies/ $\mu$ l and maximum count of $900 / \mu$ l. The mean of Candida colony number from the subject's oral cavity is 230.1 colonies $/ \mu \mathrm{L}$ and $\mathrm{SD}=246.57$. The distribution of data doesn't show a normal curve, measured by Kosmogorov-Smirrnoff $\mathrm{p}<0.05$.

From Figure 2, in positive culture subgroups the maximum value of total lymphocyte is 3166 cells $/ \mu \mathrm{L}$, minimum total lymphocyte is 162 cells $/ \mu \mathrm{L}$, mean 888.16 cells $/ \mu \mathrm{L}$ and $\mathrm{SD}=754.53$; in negative culture subgroups the maximum value of total lymphocyte is 3135 cells $/ \mu \mathrm{L}$, minimum total lymphocyte count is 1246 cells $/ \mu \mathrm{L}$, mean 2037.06 cells $/ \mu \mathrm{L}$ and $\mathrm{SD}=591.935$.

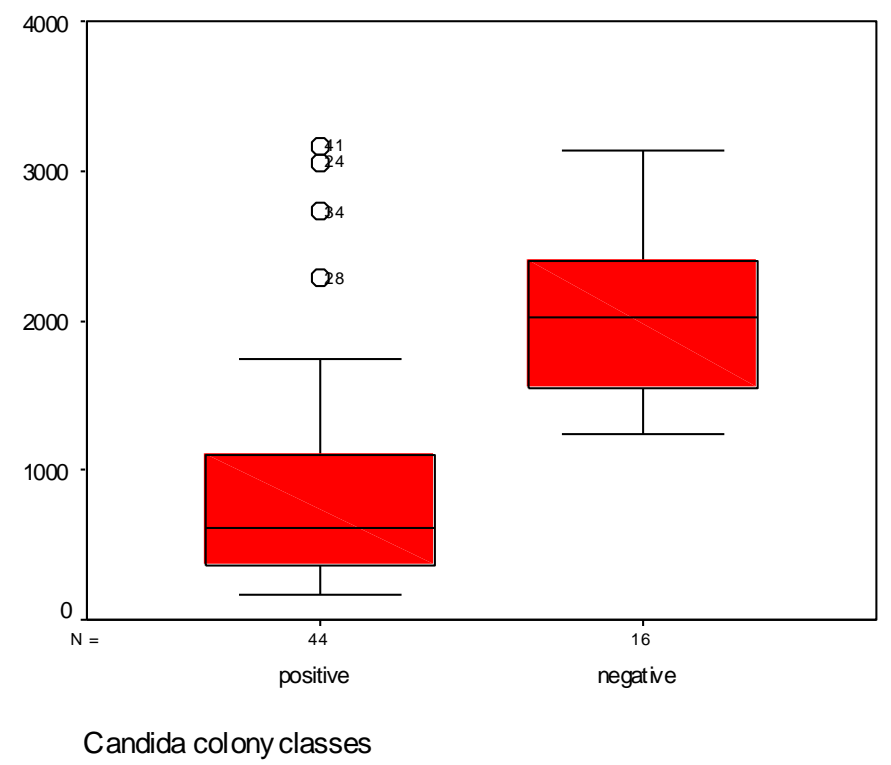

Figure 2. Boxplot of total lymphocytes and Candida colony classes. Mann Whitney test show significant differences between subgroups ( $p<0.05$ ). 
In figure 3 show the scatter diagram of number of Candida colony according to the total lymphocyte count. There were tendency of higher Candida colony to lower total lymphocyte counts despite no significant correlation statistically between the two by Spearman test. Spearman correlation test show correlation coefficient $-0.264(\mathrm{p}=0.084)$.

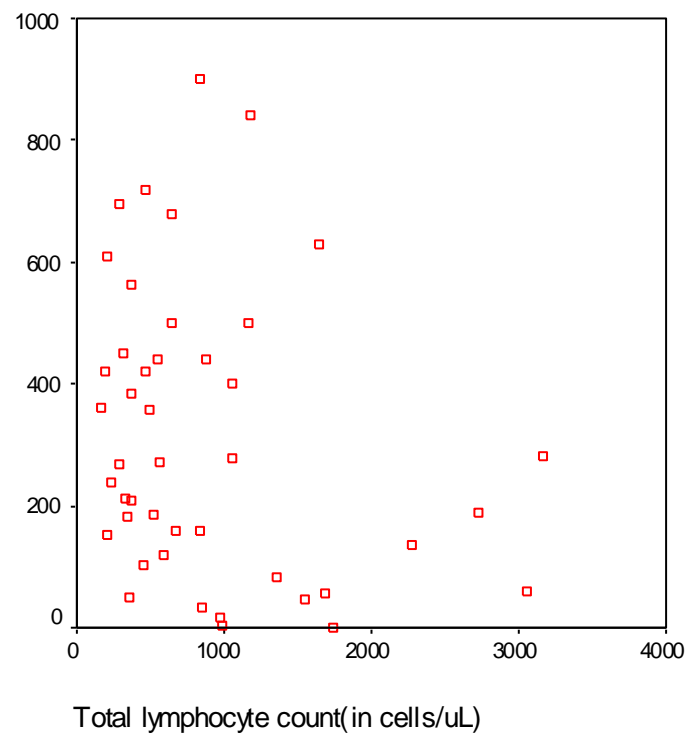

Figure 3. Scatter diagram of value between total lymphocytes and number of Candida colonies in positive class subjects

This may be associated with viral transmission, which is through syringe exchange among intravenous drug users among the young, in line with findings of viral transmission in this study, consisting of 45 subjects (75\%). This is also in line with previous studies by Pohan ${ }^{14}$ and Astoro. ${ }^{15}$

The mean total lymphocyte count was 1194.53 cells $/ \mu \mathrm{L}$. This number is almost the same as the mean value in the study by Astoro, ${ }^{15}$ and is higher than the study by Lydia, ${ }^{13}$ which is 602.2 cells $/ \mu \mathrm{L}$. The studies by Suryamin $^{20}$ and Lydia $^{13}$ stated that total lymphocyte count can be used as a predictor for CD4 count in patients with HIV infection/AIDS.

The prevalence of oropharyngeal candidiasis is 73.3\%. This is much less than the data from Cipto Mangunkusumo Hospital that found a prevalence of oral and esophageal candidosis of up to $80.8 \% \%^{3,4}$ This may be because fungal culture was not confirmed in the patients.
Growth of Candida spp colonies from the subjects of this study was found to be $73.3 \%$, with a mean number of colonies growing in the culture media of each gargle sample of 230.1 colonies.

The correlation between total lymphocyte count and the number of Candida colonies growing from the subject's oral cavity is calculated according to Spearman test. This study found no significant correlation between total lymphocyte count and the increased number of Candida colonies. The explanation for this is that total lymphocyte count changes doesn't always represents CD4 count changes, because total lymphocyte count is a sum from subsets of $\mathrm{T}$ lymphocyte (CD4 and CD8) and also B lymphocyte. A decrease in total lymphocyte count could mean a decrease in any one of those parameters. In HIV patients, the progressive loss of $\mathrm{T}$ cells numbers mostly affects CD4 helper cells, but the number of CD8 cytotoxic cells also decreased. Which subsets decrease more in HIV patients are undeterminable from total lymphocyte count. And the proneness to Candidosis oropharyng as opportunistic infection or predicting the increased intensity in Candida colonization can not be determined by total lymphocyte count only. From the distribution of data in our study show a trend of higher Candida colonies number with lower total lymphocyte count .

By comparing total lymphocyte count from Candida colony classes (positive and negative), we found significant difference in total lymphocyte count between the two classes using Mann-Whitney nonparametric test.

\section{CONCLUSIONS AND SUGGESTION}

\section{Conclusions}

- There is a prevalence rate of oropharyngeal candidiasis of $73.3 \%$ in this study.

- There is a trend of higher Candida colonies number with lower total lymphocyte count despite no significant correlation between total lymphocyte count and the number of Candida colonies in the oral cavity of patients with HIV infection/AIDS.

- There is significant different between total lymphocyte count in positive and negative Candida colonies. 


\section{Suggestions}

- A larger scale study is required to establish a cause and effect relationship from the association found in this study.

- Further evaluation is needed on the effort to increase the number of total lymphocyte count in patients with HIV infection/AIDS to prevent the incidence of oropharyngeal candidiasis in these patients.

\section{REFERENCES}

1. Djoerban Z. HIV/AIDS di Indonesia: Masa kini dan masa depan. Pidato pada Pengukuhan Sebagai Guru Besar Tetap dalam Ilmu Penyakit Dalam pada Fakultas Kedokteran Universitas Indonesia. Jakarta: 20 Desember 2003.

2. Kovacs JA, Masur H. Prophylaxis against opportunistic infections in patients with human immunodeficiendy virus infection. N Engl J Med 2000; 342(19): 1416-26.

3. Fauci AS, Lane HC. Human immunodeficiency virus (HIV): AIDS and related disorders. In: Braunwald, et.al (Eds). Harrison's Principles of Internal Medicine $15^{\text {th }}$ ed. New York: McGraw-Hill; 2001: 1852-1913.

4. Djauzi S, Djoerban Z (Ed). Penatalaksanaan infeksi HIV di pelayanan kesehatan dasar. Edisi kedua. Jakarta: Balai Penerbit FKUI; 2003.

5. Ampel NM. Emerging disease issues and fungal pathogens associated with HIV infection. Emerg Infect Dis 1996; 2 (2): 109-16.

6. Fox CR, Sande MA. Candida species. In: Wilson WR, et al (Eds). Current diagnosis \& treatment in infectious diseases. New York. McGraw-Hill;2001: 734-44.

7. Bennett JE. Candidiasis. In: Braunwald, et.al (Eds). Harrison's Principles of Internal Medicine $15^{\text {th }}$ ed. New York: McGraw-Hill; 2001: 1852-1913.

8. Cartledge JD, Midgley J, Gazzard BG. Non-albicans oral candidosis in HIV-positive patients. J Antimicr Chemotherapy 1999; 43: 419-22.

9. Sant' Ana PL, et al. Multicenter Brazilian study of oral Candida species isolated from AIDS patients. Mem Inst Oswaldo Cruz Rio de Janeiro 2002; 97(2): 253-7.
10. Sangeorzan JA, Bradley SF, He X, et al. Epidemiology of oral candidiasis in HIV-infected patients: colonization, infection, treatment, and emergence of fluconazole resistance. Am J Med 1994; 97: 339-46.

11. Vazquez JA, Sobel JD. Candidiasis. In: Dismukes WE, Pappas PG, Sobel JD(Eds). Clinical mycology. Oxford: Oxford university press; 2003: 143-87.

12. Phelan JA. Oral manifestation of human immunodefficiency virus infection. Med Clin North Am 1997; 81: 511-31.

13. Lydia A. Hitung limfosit total sebagai prediktor hitung limfosit CD4 pada penderita AIDS. Tesis. Program pendidikan dokter spesialis I. Departemen Ilmu Penyakit Dalam FKUI RSCM, Jakarta 1996.

14. Pohan HT. Clinical manifestation of HIV/AIDS patients: differences between public and private hospitals in Jakarta. Med J Indones 2004; 13: 232-6.

15. Astoro NW. Kualitas hidup penderita HIV dan faktorfaktor yang mempengaruhi. Tesis program pendidikan dokter spesialis I bidang Ilmu Penyakit Dalam. Jakarta, Fakultas Kedokteran Universitas Indonesia, 2003.

16. Ditjen PPM \& PLP Depkes RI. Statistik Kasus HIV/AIDS di Indonesia: Dilapor s.d. September 2004. Jakarta. Depkes RI, 2004.

17. UNAIDS/WHO. AIDS epidemic update 2004. Geneva: WHO/UNAIDS; 2004. [cited 2005 Jan 10]. Available from: URL: http://www.unaids.org.

18. Sherbourne CD, Hays RD, Fleishman JA, Vitiello B, Magruder KM, Bing EG, et al. Impact of psychiatric conditions on health-related quality of life in persons with HIV infections. Am J Psychiatry 2000; 157: 248-54.

19. Hays RD, Cunningham WE, Sherbourne CD, Wilson IB, Wu AW, Cleary PD, et al. Health-related quality of life in patients with Human Immunodefficiency infection in the United States: results from the HIV cost and service utilization study. Am J Med 2000; 108: 714-22.

20. Suryamin M. Hitung limfosit total sebagai indikasi memulai terapi antiretroviral pada pasien HIV/AIDS. Tesis program pendidikan dokter spesialis I bidang Ilmu Penyakit Dalam. Jakarta, Fakultas Kedokteran Universitas Indonesia, 2003. 